\title{
PENERAPAN MODEL PAIKEM UNTUK MENINGKATKAN HASIL BELAJAR IPS PADA SISWA KELAS III SDN 1 LASUSUA
}

\author{
Mariana $^{1)}$, La Ode Rafiuddin R. ${ }^{2)}$ \\ 1) SDN 1 Lasusua, Kolaka Utara, Indonesia \\ ${ }^{2)}$ Jurusan PGSD, Universitas Halu Oleo, Kendari, Indonesia \\ email: marianalss01@gmail.com
}

\begin{abstract}
Abstrak: Penelitian ini bertujuan untuk meningkatkan hasil belajar IPS materi kerja sama pada siswa kelas III SDN 1 Lasusua melalui penerapan model Pembelajaran Aktif, Inovatif, Kreatif, Efektif, dan Menyenangkan (PAIKEM). Prosedur penelitian yaitu; (a) perencanaan (planning), (b) pelaksanaan tindakan (action), (c) observasi dan evaluasi (observation and evaluation), dan (d) refleksi (reflection). Data dalam penelitian ini terdiri dari data kualitatif dan data kuantitatif. Hasil analisis penelitian menunjukkan bahwa terjadi peningkatan persentase ketuntasan hasil belajar dari siklus I sebesar 59,1\% dengan jumlah siswa yang mencapai ketuntasan hasil belajar berjumlah 13 siswa dan meningkat menjadi 90,9\% pada siklus II dengan jumlah siswa yang mencapai ketuntasan hasil belajar berjumlah 20 siswa. Kesimpulan penelitian ini yaitu hasil belajar IPS siswa kelas III SDN 1 Lasusua dapat ditingkatkan melalui penerapan model PAIKEM, hal ini dapat dilihat dari peningkatan hasil belajar, pada siklus I rata-rata hasil belajar siswa adalah 71,23 meningkat menjadi 86,52 pada siklus II. Di samping itu, terjadi peningkatan jumlah siswa yang mencapai ketuntasan belajar yaitu siklus I sebesar $59,1 \%$, meningkat menjadi $90,9 \%$ pada siklus II. Dengan demikian ketuntasan hasil belajar siswa telah mencapai KKM yang ditetapkan sekolah yaitu minimal 80\% siswa memperoleh nilai minimal 70.
\end{abstract}

Kata kunci: model pembelajaran; PAIKEM; hasil belajar

\section{APPLICATION OF PAIKEM MODEL TO IMPROVE IPS LEARNING OUTCOMES IN CLASS III STUDENTS OF SDN 1 LASUSUA}

Abstract: This study aimed to improve social studies learning outcomes on cooperation material for grade III SDN 1 Lasusua students through the application of the Active, Innovative, Creative, Effective, and Fun Learning (PAIKEM) model. Research procedures, namely; (a) planning (planning), (b) implementation of action (action), (c) observation and evaluation (observation and evaluation), and (d) reflection. The data in this study consisted of qualitative data and quantitative data. The results of the research analysis showed that there was an increase in the percentage of completeness of learning outcomes from cycle I of $59.1 \%$ with the number of students who achieved completeness of learning outcomes amounting to 13 students and increased to $90.9 \%$ in cycle II with the number of students who achieved mastery learning outcomes amounting to 20 students. The conclusion of this study is that the social studies learning outcomes of class III SDN 1 Lasusua students can be improved through the application of the PAIKEM model, this can be seen from the increase in learning outcomes, in cycle I the average student learning outcomes was 71.23 , increasing to 86.52 in cycle II. In addition, there was an increase in the number of students who achieved mastery learning, namely the first cycle of $59.1 \%$, increasing to $90.9 \%$ in the second cycle. Thus the completeness of student learning outcomes has reached the KKM set by the school, namely at least $80 \%$ of students get a minimum score of 70 .

Keywords: learning model; PAIKEM; learning outcomes 


\section{Pendahuluan}

Keberhasilan program pembelajaran di sekolah sebagai lembaga pendidikan formal sangat dipengaruhi oleh beberapa faktor yaitu: siswa, kurikulum, tenaga kependidikan, biaya, sarana dan prasarana serta faktor lingkungan. Apabila faktor-faktor tersebut dapat terpenuhi sudah tentu akan memperlancar proses pembelajaran, yang akan menunjang pencapaian hasil belajar yang maksimal, sehingga pada akhirnya akan meningkatkan mutu pendidikan.

Berbagai upaya telah dilakukan untuk meningkatkan mutu pendidikan di sekolah, antara lain dengan perbaikan mutu pembelajaran. Pembelajaran di sekolah merupakan serangkaian kegiatan yang yang dilaksanakan secara terencana. Dengan adanya perencanaan yang baik akan mendukung keberhasilan pembelajaran. Dalam perencanaan pembelajaran, perlu diketahui bahwa baik atau tidaknya pemilihan metode pembelajaran akan bergantung pada tujuan pembelajaran, kesesuaian materi pembelajaran dan tingkat kemampuan siswa, selain itu kemampuan guru untuk memanfaatkan sumber belajar yang ada di sekitar siswa juga sangat mempengaruhi sehingga belajar menarik dan berkesan dalam benak siswa yang berdampak pada peningkatan motivasi dan antusias siswa dalam belajar serta menunjang pencapaian prestasi belajar secara optimal.

Masalah rendahnya hasil belajar adalah suatu hal yang bersifat kompleks dan tidak dapat dipisahkan dengan pembelajaran dan pembelajaran juga tidak terlepas dari berbagai faktor yang mempengaruhinya, baik yang sifatnya dari dalam diri siswa maupun faktor yang berasal dari luar diri siswa. IPS merupakan salah satu mata pelajaran yang masih dianggap sulit dipahami oleh siswa, sehingga menyebabkan hasil belajar siswa belum memperlihatkan hasil yang memuaskan. Pendidikan IPS merupakan alat penting dalam menghadapi masalah kehidupan sosal yang terjadi pada setiap manusia dan masyarakat dalam kehidupan (Hadi, 2013, p.2).

Dalam belajar IPS siswa memiliki kendala yakni kurang antusias untuk belajar, siswa lebih cenderung menerima apa saja yang disampaikan oleh guru, diam dan enggan dalam mengemukakan pertanyaan maupun pendapat. Salah satu penyebabnya adalah kurangnya kreativitas guru dalam memotivasi siswa untuk mengemukakan pertanyaan maupun pendapatnya. Dalam proses pembelajaran, guru cenderung menggunakan model pembelajaran konvensional yang berpusat pada guru. Melalui metode ceramah yang mendominasi, menyebabkan siswa menjadi pasif dalam proses pembelajaran dan siswa terkesan sebagai pendengar yang baik. Padahal dalam pembelajaran, aktivitas siswa lebih diutamakan dan mesti terlibat secara mental, fisik, dan sosial untuk membangun sendiri pengetahuan yang dipelajari. Dalam hal ini guru dituntun menjadi motivator, fasilitator dalam mengorganisir kegiatan pembelajaran. Jika hal ini tidak terpenuhi dalam pembelajaran, maka dapat dipastikan pengetahuan yang dimiliki siswa akan kurang dan menyebabkan hasil belajar menjadi rendah.

Dengan berbagai permasalahan yang telah dipaparkan sebelumnya, itu bukanlah hanya sebuah artikel saja karena pada kenyataannya permasalahan yang ada juga terjadi di SDN 1 Lasusua, yang memiliki data faktual bahwa berdasarkan hasil belajar siswa pada pelajaran IPS semester ganjil tahun ajaran 2015/2016 ditemukan bahwa ulangan harian siswa materi "Kerja Sama" masih rendah atau belum mencapai Kriteria Ketuntasan Minimal (KKM) sekolah yakni 70. Dari jumlah 24 siswa hanya 15 orang atau 62,5\% yang mencapai KKM sekolah, dan yang belum mencapai KKM sekolah secara individual dengan nilai 70 adalah 13 orang atau 58,4\%. Hal ini merupakan masalah yang harus diatasi oleh guru dengan melakukan alternatif pada pembelajaran yakni menggunakan model pembelajaran yang lebih mengutamakan keaktifan, penemuan hal-hal baru bagi siswa, menciptakan siswa yang kreatif, pembelajaran yang efektif dan penciptaan suasana yang menyenangkan. Model pembelajaran yang dimaksud adalah Pembelajaran Aktif, Inovatif, Kreatif, Efektif dan Menyenangkan. 
Peneliti memilih model ini karena menganggap model pembelajaran ini sangatlah kompleks dan sangat cocok diterapkan untuk meningkatkan hasil belajar siswa.

Model pembelajaran PAIKEM adalah model pembelajaran aktif, inovatif, kreatif, efektif, dan menyenangkan yang diberikan kepada siswa secara optimal untuk mencapai tujuan pembelajaran dalam suasana yang tidak membosankan siswa (Marinta, dkk., 2014, p.44-45). Menurut Slameto dalam Siregar, dkk. (2017, p.744), PAIKEM mengandung makna pembelajaran yang dirancang agar mengaktifkan anak, mengembangkan inovasi dan kreativitas sehingga efektif namun tetap menyenangkan. Secara garis besar, Amri dan Iif Khoiru dalam Purwandari, dkk (2013, p.5) menyatakan bahwa, penerapan PAIKEM dalam proses pembelajaran dapat digambarkan sebagai berikut: (1) siswa langsung terlibat berbagai kegiatan yang mengembangkan pemahaman dan kemampuan mereka dengan penekanan pada belajar melalui praktik, (2) guru dituntut menggunakan berbagai alat bantu dan berbagai cara dalam membangkitkan semangat, termasuk menggunakan lingkungan sebagai sumber belajar untuk menjadikan pembelajaran menarik, menyenangkan, dan cocok bagi siswa, (3) guru harus bisa mengatur kelas dengan berbagai variasi seperti memajang buku-buku dan bahan belajar yang lebih menarik dan menyediakan alat-alat pembelajaran, (4) guru menerapkan tentang cara mengajar yang lebih kooperatif dan interaktif, termasuk cara belajar kelompok dalam segala suasana, (5) guru mendorong, memberikan motivasi siswa untuk menemukan caranya sendiri dalam pemecahan suatu masalah, untuk mengungkapkan gagasannya, dan melibatkan siswa dalam menciptakan lingkungan sekolahnya.

Selain itu menurut Jauhar dalam Armini, dkk (2014, p.4) PAIKEM merupakan salah satu pendekatan mengajar (approach to teaching) yang digunakan bersama metode tertentu dan berbagai media pelajaran yang disertai penataan lingkungan yang sedemikian rupa agar proses pembelajaran menjadi aktif, inovatif, kreatif, efektif dan menyenangkan khususnya dalam pembelajaran PKn.

Model ini juga dianggap cocok bagi peneliti karena dalam model ini memberi pengalaman yang berkesan bagi siswa sehingga siswa mudah mengingat akan apa yang telah dipelajarinya. Bukan hanya itu, model pembelajaran ini juga dipilih oleh peneliti karena dianggap dapat memacu siswa dalam mengembangkan pokok pikirannya untuk memecahkan masalah yang telah diberikan oleh guru.

Asmiar (2011) dalam penelitiannya di Kelas III $^{\mathrm{B}}$ SD Negeri 07 Baruga Kecamatan Baruga Kota Kendari menyimpulkan pada siklus I ketuntasan belajar siswa mencapai persentase $73,05 \%$, sedangkan pada siklus II mencapai persentase ketuntasan $87,65 \%$. Disimpulkan bahwa penerapan pendekatan model PAIKEM pada mata pelajaran IPS dapat meningkatkan hasil belajar siswa kelas III $^{\mathrm{B}}$ SD Negeri 07 Baruga Kecamatan Baruga Kota Kendari.

Berdasarkan uraian di atas, peneliti merencanakan untuk melaksanakan penelitian tindakan kelas dengan judul: "Penerapan Model Pembelajaran Aktif, Inovatif, Kreatif, Efektif, dan Menyenangkan (PAIKEM) untuk Meningkatakan Hasil Belajar Siswa pada Mata Pelajaran IPS Materi Kerja Sama di Kelas III SDN 1 Lasusua Kabupaten Kolaka Utara"

Masalah dalam penelitian ini adalah: 1) Apakah penerapan model Pembelajaran Aktif, Inovatif, Kreatif, Efektif, dan Menyenangkan (PAIKEM) dapat meningkatkan hasil belajar IPS materi kerja sama pada siswa kelas III SDN 1 Lasusua Kabupaten Kolaka Utara? 2) Apakah penerapan model Pembelajaran Aktif, Inovatif, Kreatif, Efektif, dan Menyenangkan (PAIKEM) dapat meningkatkan aktivitas mengajar guru kelas III SDN 1 Lasusua Kabupaten Kolaka Utara? 3) Apakah penerapan model Pembelajaran Aktif, Inovatif, Kreatif, Efektif, dan Menyenangkan (PAIKEM) dapat meningkatkan aktivitas belajar siswa kelas III SDN 1 Lasusua Kabupaten Kolaka Utara? Tujuan penelitian ini adalah 1) Untuk meningkatkan hasil belajar IPS materi kerja sama pada siswa kelas III SDN 1 Lasusua melalui 
penerapan model Pembelajaran Aktif, Inovatif, Kreatif, Efektif, dan Menyenangkan (PAIKEM). 2) Untuk meningkatkan aktivitas mengajar guru kelas III SDN 1 Lasusua melalui penerapan model Pembelajaran Aktif, Inovatif, Kreatif, Efektif, dan Menyenangkan (PAIKEM). 3) Untuk meningkatkan aktivitas belajar siswa kelas III SDN 1 Lasusua melalui penerapan model Pembelajaran Aktif, Inovatif, Kreatif, Efektif, dan Menyenangkan (PAIKEM). Penelitian ini diharapkan dapat memberikan manfaat bagi guru, siswa, sekolah dan penelitian lainnya.

\section{Metode}

Jenis penelitian adalah penelitian tindakan kelas (PTK. dilaksanakan pada kelas III semester Ganjil Tahun Pelajaran 2016/2017 pada SDN 1 Lasusua Kabupaten Kolaka Utara dengan subyek dalam penelitian ini adalah siswa Kelas III SDN 1 Lasusua Kabupaten Kolaka Utara semester I Tahun Pelajaran 2016/2017 dengan jumlah siswa 22 orang. Penelitian tindakan kelas ini dilaksanakan dalam dua siklus yang terdiri dari empat tahapan yaitu perencanaan, pelaksanaan tindakan, observasi dan evaluasi serta refleksi Jenis data dalam penelitian ini adalah data kualitatif dan kuantitatif. Data kualitatif berupa kegiatan proses pembelajaran aktivitas belajar siswa dan aktivitas guru. Data kuantitatif berupa nilai hasil belajar siswa. Sumber data dalam penelitian ini adalah guru dan siswa Kelas III SDN 1 Lasusua Kabupaten Kolaka Utara.

Data kualitatif akan dianalisis secara deskriptif kualitatif berdasarkan observasi, sedangkan data kuantitatif dianalisis secara kuantitatif menggunakan rumus:

1. Untuk menghitung nilai siswa

$$
\mathrm{NS}=\frac{\text { Total skor yang di capai }}{\text { skormaksimal }} \times 100 \quad \text { (Sudjana, 1999, p.94) }
$$

2. Menghitung nilai rata-rata siswa

$$
\overline{\mathrm{X}}=\frac{\Sigma \mathrm{x}_{\mathrm{i}}}{\mathrm{n}}
$$

(Usman dan Setiawati, 2001, p.139)

3. Menentukan persentase ketuntasan :

$\% \mathrm{~TB}=\frac{\Sigma \mathrm{TB}}{\mathrm{n}} \times 100 \%$

Indikator kinerja dalam penelitian ini adalah hasil belajar mata pelajaran IPS dikatakan berhasil apabila minimal $80 \%$ dari siswa yang menjadi subyek penelitian telah memperoleh nilai $\geq 70$.

\section{Hasil}

\section{Hasil Belajar Siswa}

Pada pembelajaran siklus I, siswa yang memperoleh nilai antara 0-69 (tidak tuntas) berjumlah 9 orang siswa atau sebesar 40,9\%, dan siswa yang memperoleh nilai rentang 70 100 (tuntas) berjumlah 13 orang siswa atau sebesar 59,1\%. Ketuntasan belajar siswa mencapai 59,1\%, yang ditunjukkan oleh jumlah siswa yang memperoleh nilai $\geq 70$ berjumlah 13 orang siswa dari 22 siswa keseluruhan. Pada pembelajaran siklus II, siswa yang memperoleh nilai antara 0-69 (tidak tuntas) berjumlah 2 orang siswa atau sebesar 9,1\% dan siswa yang memperoleh nilai rentang 70-100 (tuntas) berjumlah 20 orang siswa atau sebesar 90,9\%. Peningkatan ketuntasan hasil belajar siswa dapat dilihat pada Gambar 1 berikut: 


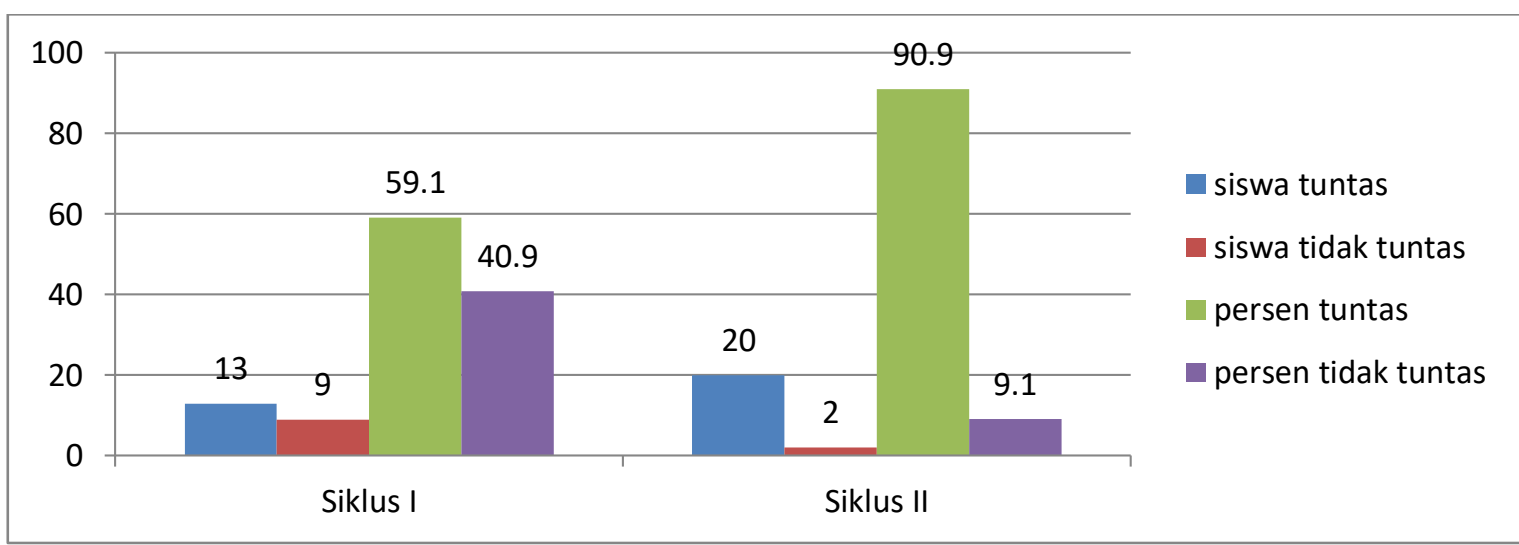

Gambar 1. Grafik Ketuntasan Hasil Belajar Siswa Siklus I dan Siklus II

\section{Aktivitas Guru}

Skor perolehan dan persentase keberhasilan aktivitas mengajar guru pada penelitian ini menunjukkan peningkatan. Hal ini terlihat dari skor perolehan guru pada siklus I pertemuan pertama adalah 2 atau sebesar 50\% dan pertemuan kedua adalah 2 atau sebesar 50\%. Pada siklus II skor perolehan dan persentase keberhasilan aktivitas mengajar guru mengalami menjadi 4 atau sebesar $100 \%$. Peningkatan skor perolehan dan persentase keberhasilan aktivitas mengajar guru pada penelitian ini dapat dilihat pada gambar berikut:

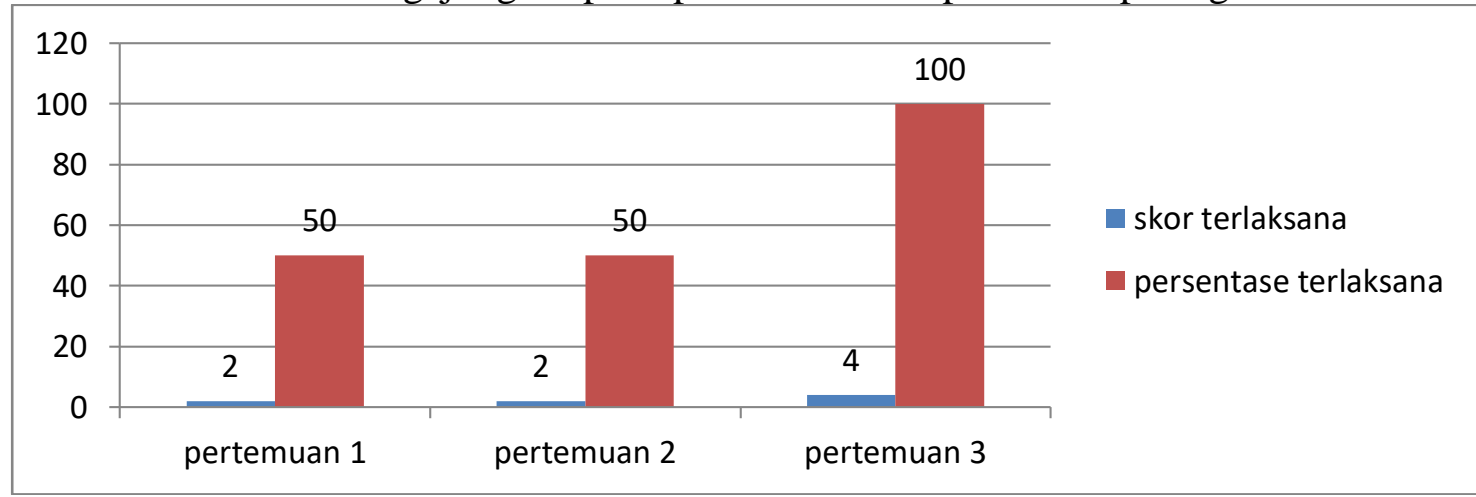

Gambar 2. Grafik Skor dan Persentase Aktivitas Mengajar Guru Siklus I dan Siklus I

\section{Aktivitas Siswa}

Skor perolehan dan persentase keberhasilan aktivitas belajar siswa pada penelitian ini menunjukkan peningkatan. Dari hasil penelitian diperoleh bahwa skor aktivtas siswa pada pembelajaran siklus I pertemuan pertama adalah 2 dan pertemuan kedua adalah 2, siklus II adalah 4 sehingga persentase keberhasilan aktivitas belajar siswa pada siklus I pertemuan pertama sebesar 50\% dan pertemuan kedua 50\%. Persentase keberhasilan aktivitas belajar siswa pada siklus II meningkat menjadi $100 \%$. Peningkatan aktivitas belajar siswa setiap siklus dapat dilihat pada gambar berikut:

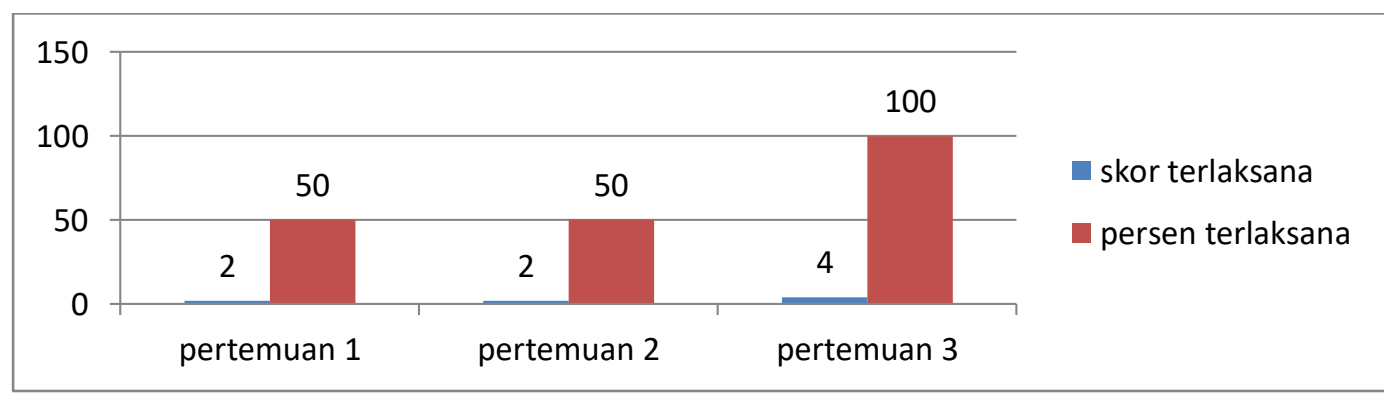

Gambar 3. Grafik Skor dan Persentase Aktivitas Belajar Siswa Siklus I dan Siklus II 


\section{Pembahasan}

\section{Aktivitas Mengajar Guru}

Selama proses pembelajaran peneliti mengadakan observasi untuk mengetahui kelemahan dan keberhasilan dalam proses pembelajaran. Hal-hal yang observasi aktivitas mengajar guru dan aktivitas belajar siswa pada proses pembelajaran. Hasil observasi aktivitas mengajar guru pada penelitian tindakan pembelajaran menjadi dasar untuk menentukan skor perolehan guru. Skor perolehan guru digunakan untuk menentukan persentase keberhasilan aktivitas mengajar guru.

Adanya kekurangan-kekurangan yang terjadi pada tindakan siklus I, sehingga aktivitas mengajar guru pada tindakan I pertemuan 1 hanya mencapai 50\% dari keseluruhan kegiatan pembelajaran dan pada pertemuan kedua mencapai 50\%. Sebelum melaksanakan penelitian pada tindakan II, peneliti mengadakan refleksi bersama observer untuk memperbaiki kekurangan-kekurangan pada tindakan I. Pada pelaksanaan tindakan II, keberhasilan aktivitas mengajar guru sudah menggembirakan bagi peneliti, karena menurut hasil observasi pelaksanaan skenario pembelajaran aktivitas guru telah mencapai $100 \%$. Hasil ini menunjukkan bahwa aktivitas mengajar guru telah terlaksana dengan baik karena semua skenario dalam pembelajaran.

Skor perolehan dan persentase keberhasilan aktivitas mengajar guru pada penelitian ini menunjukkan peningkatan. Hal ini terlihat dari skor perolehan guru pada siklus I pertemuan pertama adalah 2 atau sebesar 50\% dan pertemuan kedua adalah 2 atau sebesar $50 \%$. Pada siklus II skor perolehan dan persentase keberhasilan aktivitas mengajar guru mengalami menjadi 4 atau sebesar $100 \%$.

\section{Aktivitas Belajar Siswa}

Keberhasilan aktivitas belajar siswa pada tindakan I pertemuan 1, dari 4 skenario pembelajaran yang terlaksana hanya 2 skenario pembelajaran atau sebesar $50 \%$ dan pada pertemuan 2 hanya mencapai 2 skenario pembelajaran atau sebesar 50\%. Ketidakberhasilan aktivitas belajar siswa pada tindakan I disebabkan karena peneliti masih terbiasa dengan cara mengajar model lama, siswa dibiarkan sendiri-sendiri dalam mengerjakan tugas atau tidak membimbing kelompok dengan baik dan siswa masih merasa asing dengan belajar dalam kelompok sehingga belum dapat menyesuaikan diri dengan teman dalam kelompoknya. Halhal tersebut menyebabkan keaktifan siswa dalam bekerja sama dalam kelompok, partisipasi siswa dalam kelompok untuk menyelesaikan tugas, memberikan gagasan dalam menyelesaikan tugas, dan keberanian siswa dalam mengemukakan pendapat serta tanggung jawab siswa dalam kelompok, tidak sesuai dengan yang diharapkan dalam penerapan model pembelajaran PAIKEM. Setelah menerima saran-saran dari observer berdasarkan hasil diskusi pada kegiatan refleksi, maka peneliti mengadakan tindakan siklus II dengan penerapan model pembelajaran PAIKEM mata pelajaran IPS materi kerja sama.

Pada siklus II, keberhasilan aktivitas belajar siswa pada tindakan II dari 4 skenario pembelajaran yang terlaksana sebanyak 4 skenario pembelajaran atau sebesar $100 \%$. Aktivitas belajar siswa dalam kelompok pada tindakan II, sesuai dengan pengamatan peneliti melalui lembar pengamatan kerja kelompok telah berjalan dengan baik. Setiap anggota kelompok sudah dapat berpatisapasi dengan aktif, saling memberi gagasan dengan berbagi tugas dalam menyelesaikan LKS dengan penuh tanggung jawab dan siswa nampak ceria dalam bekerja. Dengan keberhasilan aktivitas mengajar guru dan aktivitas belajar siswa yang sudah cukup baik, maka mempengaruhi hasil belajar siswa.

Skor perolehan dan persentase keberhasilan aktivitas belajar siswa pada penelitian ini menunjukkan peningkatan. Dari hasil penelitian diperoleh bahwa skor aktivtas siswa pada pembelajaran siklus I pertemuan pertama adalah 2 dan pertemuan kedua adalah 2, siklus II 
adalah 4 sehingga persentase keberhasilan aktivitas belajar siswa pada siklus I pertemuan pertama sebesar $50 \%$ dan pertemuan kedua 50\%. Persentase keberhasilan aktivitas belajar siswa pada siklus II meningkat menjadi $100 \%$.

\section{Hasil Belajar Siswa}

Berdasarkan nilai yang diperoleh siswa, guru melakukan analisis untuk menentukan ketuntasan belajar siswa. Analisis ketuntasan hasil belajar siswa diambil berdasarkan nilai tes hasil belajar siswa siklus I dan tes hasil belajar siswa siklus I I. Pada pembelajaran siklus I, siswa yang memperoleh nilai antara 0-69 (tidak tuntas) berjumlah 9 orang siswa atau sebesar $40,9 \%$, dan siswa yang memperoleh nilai rentang 70-100 (tuntas) berjumlah 13 orang siswa atau sebesar 59,1\%. Ketuntasan belajar siswa mencapai 59,1\%, yang ditunjukkan oleh jumlah siswa yang memperoleh nilai $\geq 70$ berjumlah 13 orang siswa dari 22 siswa keseluruhan. Pada pembelajaran siklus II, siswa yang memperoleh nilai antara 0-69 (tidak tuntas) berjumlah 2 orang siswa atau sebesar 9,1\% dan siswa yang memperoleh nilai rentang 70-100 (tuntas) berjumlah 20 orang siswa atau sebesar 90,9\%. Sehingga ketuntasan belajar siswa pada siklus II telah mencapai indikator kinerja yaitu minimal $80 \%$ siswa memperoleh nilai $\geq 70$.

Ketuntasan belajar siswa mengindikasikan bahwa indikator keberhasilan penelitian yang ditetapkan telah tercapai. Sedangkan hasil observasi terhadap pelaksanaan pembelajaran bisa dikatakan sempurna, yakni seluruh komponen dalam skenario pembelajaran telah dilaksanakan dengan baik sesuai yang diharapkan. Karena kedua indikator telah tercapai, maka hipotesis tindakan telah tercapai yakni: penerapan model pembelajaran PAIKEM dapat meningkatkan hasil belajar IPS siswa pada materi kerja sama di kelas III SDN 1 Lasusua.

Dari hasil evaluasi tersebut menunjukan bahwa usaha dan keberhasilan belajar dipengaruhi oleh berbagai faktor. Hal ini sesuai dengan yang dikemukakan oleh Syah (2010, p.132) bahwa hasil belajar dipengaruhi oleh beberapa faktor yaitu, faktor internal adalah faktor yang berasal dari diri siswa, faktor eksternal adalah faktor yang berasal dari luar diri siswa dan faktor pendekatan belajar yaitu jenis upaya belajar yang meliputi strategi dan metode yang digunakan untuk melakukan pembelajaran. Ismail \& Elias (2006, p.21) mengemukakan bahwa "In order to fully grasp the concept, learners must experience inquiry directly to gain a deep understanding of its characteristics." Hasil penelitian ini bila dikaitkan dengan teori masih relevan.

Karena indikator keberhasilan dalam penelitian ini telah tercapai dalam hal ini aktivitas belajar siswa selama proses pembelajaran sudah cukup baik dan minimal $80 \%$ siswa telah memperoleh nilai $\geq 70$. Maka hipotesis tindakan dalam penelitian ini telah tercapai yaitu hasil belajar IPS dapat ditingkatkan melalui penerapan model pembelajaran PAIKEM pada materi kerja sama di kelas III SDN 1 Lasusua.

Peran aktif siswa dalam pembelajaran sangat penting dalam rangka pembentukan kreativitas yang menghasilkan semangat dan motivasi belajar. Seseorang bisa dikatakan kreatif apabila ia secara konsisten dan terus menerus menghasilkan sesuatu yang kreatif, yaitu hasil yang asli/orisinal dan sesuai dengan keperluan. Kreativitas siswa bisa dilihat pada kemampuannya dalam mengajukan pertanyaan maupun menjawab pertanyaan. Selain itu kreatifitas siswa juga bisa dilihat dari kecekatannya dalam mengikuti proses pembelajaran di dalam kelas. Kreatif juga dimaksudkan guru mampu memilih materi yang akan diberikan kepada siswa agar materi yang diberikan bisa sesuai dengan kemampuan siswa, memilih metode pembelajaran yang dapat mempermudah pemahaman siswa tentang materi yang diberikan dan memilih media yang tepat untuk memperlancar proses pembelajaran serta mampu menentukan evaluasi yang tepat untuk mengukur tingkat penguasaan siswa terhadap materi yang diberikan. 


\section{Simpulan}

1. Aktivitas mengajar IPS guru kelas III SDN 1 Lasusua dapat ditingkatkan melalui penerapan model PAIKEM. Persentase keberhasilan aktivitas mengajar guru pada siklus I pertemuan pertama sebesar 50\% dan pertemuan kedua 50\%. Persentase keberhasilan aktivitas mengajar guru pada siklus II meningkat menjadi $100 \%$.

2. Aktivitas belajar IPS siswa kelas III SDN 1 Lasusua dapat ditingkatkan melalui penerapan model PAIKEM. Persentase keberhasilan aktivitas belajar siswa pada siklus I pertemuan pertama sebesar 50\% dan pertemuan kedua 50\%. Persentase keberhasilan aktivitas belajar siswa pada siklus II meningkat menjadi $100 \%$.

3. Hasil belajar IPS siswa kelas III SDN 1 Lasusua dapat ditingkatkan melalui penerapan model PAIKEM, hal ini dapat dilihat dari peningkatan hasil belajar, pada siklus I rata-rata hasil belajar siswa adalah 71,21 meningkat menjadi 86,52 pada siklus II. Di samping itu, terjadi peningkatan jumlah siswa yang mencapai ketuntasan belajar yaitu siklus I sebesar $59,1 \%$, meningkat menjadi $90,9 \%$ pada siklus II. Dengan demikian ketuntasan hasil belajar siswa telah mencapai KKM yang ditetapkan sekolah yaitu minimal $80 \%$ siswa memperoleh nilai minimal 70.

\section{Referensi}

Armini, Ni Wy. Yanti, Md. Putra, Sujana, I Wy. (2014). Pendekatan PAIKEM Berpengaruh Terhadap Hasil Belajar PKn Siswa Kelas V SD Gugus Ii Pangeran Diponegoro, Denpasar Barat Tahun Ajaran 2013/2014. Jurusan PGSD Vol: 2 No: 1 Tahun: 2014. 1-10. https://ejournal.undiksha.ac.id/index.php/JJPGSD/article/view/1883

Asmiar, 2011. Penerapan Pendekatan Model PAIKEM Pada Mata Pelajaran IPS Dalam Meningkatkan Hasil Belajar Siswa Kelas IIIB SD Negeri 07 Baruga Kecamatan Baruga Kolaka Utara. Kendari: Skripsi Universitas Halu Oleo.

Hadi, Yul Alfian, N. Dantes, A.A.I.N. \& Marhaeni. (2013). Pengaruh Strategi PAIKEM Berbantuan Media Gambar Terhadap Hasil Belajar IPS Siswa Kelas V SDN 6 Korleko Kecamatan Labuhan Haji Kabupaten Lombok Timur Tahun Pelajaran 2012/2013. Program Studi Pendidikan Dasar (Volume 3 Tahun 2013). 1-8. https://media.neliti.com/media/publications/121349-ID-pengaruh-strategi-paikemberbantuan-medi.pdf

Ismail, Noriah \& Elias, S. (2006). Inquiry-Based Learning: An Innovative Teaching Method Article. English Language Journal (2006) Vol.2(1): 13-24. UPSI Malaysia. https://www.researchgate.net/publication/259632827

Marinta, Fungki Dwi, Khutobah, Marjono. (2014). Penerapan Model Pembelajaran PAIKEM Untuk Meningkatkan Aktivitas dan Hasil Belajar Siswa Kelas IV Bidang Studi IPS Pada Pokok Bahasan Jenis dan Persebaran SDA Serta Pemanfaatannya di SDN Tempursari 01 Tahun Pelajaran 2012/2013. Jurnal Edukasi UNEJ 2014, I (1): 44-47. http://jurnal.unej.ac.id/index.php/JEUJ/article/view/1033

Nana Sudjana. (1999). Penilaian Hasil Proses Belajar Mengajar. Bandung: Remaja Roesdakarya. 
Purwandari, Ni Md Yeni, I Nym Arcana, \& Riastini, Pt Nanci. (2013). Pengaruh Pendekatan Paikem Terhadap Hasil Belajar IPA Siswa Kelas V SD Negeri 2 Lelateng. Mimbar $\begin{array}{llllll}\text { PGSD Undiksha Vol } 1, \quad \text { No } & 1 & \text { (2013). } & 1-10 .\end{array}$ DOI: http://dx.doi.org/10.23887/jijggsd.v1i1.711

Siregar, Pariang Sonang, \& Lia, Wardani, \& Hatika, Rindi Genesa. (2017). Penerapan Pendekatan Pembelajaran Aktif Inovatif Kreatif Efektif Dan Menyenangkan (PAIKEM) Pada Pembelajaran Matematika Kelas IV SD Negeri 010 Rambah. Jurnal Pemikiran dan Pengembangan SD Volume 5, Nomor 2, September 2017. 743-749. http://ejournal.umm.ac.id/index.php/jp2sd/article/viewFile/4823/4957

Syah, Muhibbin. (2010). Psikologi Pendidikan Dengan Pendekatan Baru. Bandung:PT. Remaja Rosdakarya.

Usman, Moh Uzer dan Lilis Setiawati. (2001). Upaya Optimalisasi Kegiatan Belajar. Mengajar. Bandung: Remaja Rosdakarya. 